\title{
Practical uses of peroxidase activity as a predictive marker of rooting performance of micropropagated shoots *
}

\author{
T Gaspar *, C Kevers, JF Hausman, JY Berthon, V Ripetti
}

Université de Liège, Institut de Botanique B 22, Hormologie Fondamentale et Appliquée, Sart Tilman, B-4000 Liège, Belgium

(COST Meeting, 21-23 May 1992, Dijon, France)

\begin{abstract}
Summary - A peak of specific peroxidase activity (increase in enzyme activity followed by decrease) has generally been found in crude extracts of stem- or shoot-cuttings prior to root formation. Effectors, some of them of a phenolic nature, play a role in these changes in peroxidase activity. This may explain discrepancies in some investigations dealing with partially purified extracts or cell fractions. The peroxidase peak does not terminate the rooting inductive period as proposed some years ago, but rather the initiative phase before identification and growth of endogenous root primordia. Depending upon the materials studied, characteristics of the peroxidase peak such as precocity of appearance, height, and velocity of decrease have been correlated with ulterior rooting performance. Physical and/or chemical factors which were able to modulate the peak also had effects on subsequent rooting rate. An early test using peroxidase activity of extracts made from shoots before transferring to rooting media determined the phenol compounds capable of enhancing the rooting process and the moment of application in relation to the peroxidase peak.
\end{abstract}

peroxidase / rooting

Résumé - Utilisation pratique de l'activité de la peroxydase pour prédire les performances d'enracinement de tiges. Un pic d'activité peroxydase spécifique (augmentation de l'activité de l'enzyme suivie par une décroissance) a été trouvé en général dans les extraits bruts de boutures de tiges avant la formation de racines. Des effecteurs, dont certains sont de nature phénolique, jouent un rôle dans ces variations de l'activité peroxydase. Cela peut expliquer les désaccords entre des travaux sur des extraits ou des fractions cellulaires partiellement purifiés. Le pic de peroxidase ne termine pas la période d'induction de l'enracinement, comme on le proposait il y a quelques années, mais plutôt la période d'initiation avant lidentification et la croissance de primordia de racines endogènes. Suivant le matériel étudié, des caractéristiques du pic de peroxydase comme la précocité de son apparition, sa hauteur, et la vitesse de diminution ont été associées aux performances ultérieures d'enracinement. Les facteurs chimiques ou physiques qui modulent le pic ont aussi des effets sur la proportion d'enracinement subséquent. Un test précoce, utilisant l'activité peroxydase d'extraits de tiges avant de les transférer au milieu d'enracinement permet d'identifier les composés phénoliques capables de favoriser le processus d'enracinement et d'en déterminer le moment d'application par rapport au pic de peroxydase.

peroxydase / enracinement

* Correspondence and reprints 


\section{HISTORICAL BACKGROUND}

The early observation that exogenously applied natural or synthetic auxins favour rooting of cuttings has been repeatedly confirmed and auxins have been used in conventional horticulture for a long time. Vegetative propagation of several plants through tissue culture, ie, micropropagation, also exploits the rooting properties of auxins (Gaspar and Coumans, 1987). The rooting properties of exogenously applied auxins have automatically (and unfortunately ?) led to 2 concepts in the mind of plant physiologists: first, that cuttings or shoots must necessarily accumulate a certain amount of natural or synthetic auxins in order to be able to root; and second, that the applied auxins simply increase the bulk of endogenous auxins. Until recently, experiments aiming at establishing a relationship between (a high endogenous) auxins level and rooting led to very different results (Gurumurti et al, 1984; Haissig, 1986; Jackson, 1986; Davis et al, 1988; Gaspar and Hofinger, 1988). These discrepancies may be explained by:

- degradation and/or loss to varying degrees of the extracted endogenous auxin, depending upon the different techniques used;

- the various biological or biochemical estimation tests which differed greatly in their sensitivity;

- estimations which were made without reference to advancement of the rooting process.

Synthetic auxins may not use the same auxin receptors or act via the same pathways as endogenously produced auxins. As a matter of fact, it is quite clear that synthetic auxins may initiate a series of signals from the exterior of the cells before their penetration (Millet and Greppin, 1990).

Several papers have reported an auxincontent regulating role for the so-called auxinoxidase system - thus an inverse relationship between the endogenous IAA level of a plant tissue or organ and its IAA-oxidase activity (Pilet and Gaspar, 1968); many researchers therefore investigated the changes in IAA-oxidase activity in relation to rooting (Mato and Vieitez, 1986; see ref in Bhattacharya, 1988; Moncousin, 1991). The activity of the so-called IAA-oxidase system was later attributed to one or several peroxidases (Gaspar et al, 1982). Because the measurement of peroxidase activity is simpler than that of IAA-oxidase activity, relationships between different aspects of rooting and chang- es in peroxidase and isoperoxidase activity have been investigated by many authors.

\section{A PEROXIDASE ACTIVITY PEAK PRECEDING ROOTING. THE CONCEPT OF AN INDUCTIVE PROCESS}

Analyses of changes in total peroxidase activity and in the isoperoxidase spectrum in the course of rooting in microcuttings of different Prunus (Quoirin et al, 1974) and Asparagus (Van Hoof and Gaspar, 1976) species, and in epidermal layers of tobacco (Gaspar et al, 1977; Thorpe et $a l, 1978)$ led to the production of a general curve (Gaspar, 1981). It appeared that root formation occurred after the cutting had reached and passed a peak of maximum enzyme activity. The activity and/or number of acidic isoperoxidases increased continuously during the course of the process which means that the peak of peroxidase activity was due to an inverse variation in the activity of the basic isoenzymes before and after the peak (fig 1). Such changes in peroxidase activity in the course of root formation, most of them involving a passage through a peak, were measured in many other materials (Chandra et al, 1971; Molnar and Lacroix, 1972; Dalet and Cornu, 1986, 1989; Gebhardt, 1986; Berthon et al, 1987; Mato et al, 1988; Gonzalez et al, 1991; Kevers and Gaspar, 1992). They apparently corresponded to parallel changes in IAAoxidase activity (Mato and Vieitez, 1986; refs in Bhattacharya, 1988; Ben-Efraim et al, 1990). In some cases, peroxidase activity of the shootcuttings dropped immediately after transfer from a multiplication to an auxin-based rooting medium. This was followed by the rapid emergence of root primordia (Quoirin et al, 1974; Van Hoof and Gaspar, 1976). It was later shown that the elevation and peaking of peroxidase activity preceding rooting might already take place at the end of the foregoing multiplication/elongation cycle (Druart et al, 1982; Hausman et al, 1990).

There was an apparent coincidence between the peroxidase peak and the first visible signs of differentiation (Gaspar et al, 1977) which led to the hypothesis that the period of peroxidase elevation up to the peak corresponded to an inductive or preparatory phase of rooting occurring before any visible morphological or histological event (Gaspar, 1981). The recognition of such an inductive phase for rooting was relatively new and rarely discussed before that time, although 

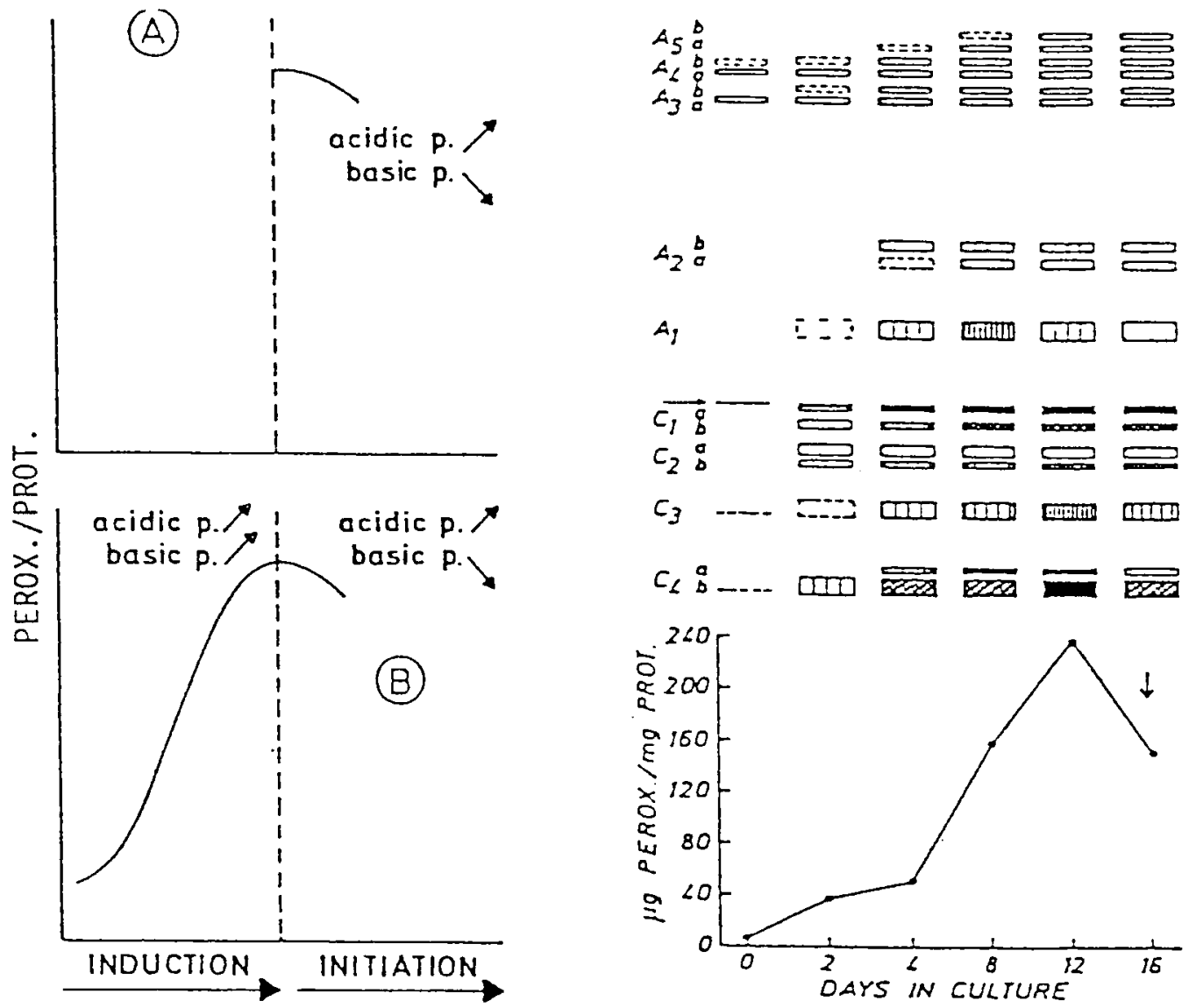

Fig 1. Left : schematic representation of the variation in specific peroxidase activity during the inductive and initiative phases of rooting by preinduced (A) and non-preinduced (B) explants (from Gaspar, 1981). Right : peroxidase zymograms and changes in total specific peroxidase activity during root formation from epidermal layers of tobacco cultured for $16 \mathrm{~d}$. Arrow indicates the time of visible appearance of roots (from Thorpe et al, 1978).

such an induction concept had long been acquired for the flowering process.

That the peroxidase peak was associated with the first cell divisions, ie that the peroxidase peak terminated the inductive period of rooting, was questioned by Jarvis (1986). This author placed the end of the rooting-induction phase (corresponding to the biochemical changes preceding cytological and histological events) before the peroxidase peak. As described hereafter, our further studies confirmed this view (Moncousin et al, 1988; Gaspar et al, 1990).

Although the increase in peroxidase activity preceding rooting has generally been noticed, some research workers were unable to demonstrate the peak and subsequent decrease in enzyme activity (Gebhardt, 1985; Pythoud and Buchala, 1986; Patience and Alderson, 1987; de Klerk et al, 1990). The explanation of these dis- crepancies may stem from the fact that in these studies, peroxidase activity was measured in purified extracts and/or not expressed per unit protein. When well evidenced, the (specific) peroxidase activity peak was measured in crude extracts where (poly)phenols apparently modulated the enzyme activity (Druart et al, 1982; Mato et al, 1988; Gaspar et al, 1990; Berthon et al, 1990b). We have further shown (Aghmir et al, 1991) that none of the cell fractions (extracellular, soluble, membrane, wall ionic, wall covalent) separated from a crude extract (of Rhododendron shoots) showed the typical increase and subsequent decrease of peroxidase activity, whereas the total extract did. This indicates that the peroxidase peak was not only the result of changes in proteinic enzyme activities but also of changes in their effectors. The results of Curir et al (1989) indirectly confirmed this view. 


\section{ROOTING AS A SERIES OF SUCCESSIVE PHYSIOLOGICAL PHASES. REFINEMENT OF THE KINETIC VARIATION OF PEROXIDASE ACTIVITY. RELATIONSHIP WITH THE ENDOGENOUS AUXIN LEVEL}

Rooting has been described to occur in at least 6 successive interdependent phases (Favre, 1973; Mitsuhashi-Kato et al, 1978a, b; Moncousin et al, 1988; Berthon et al, 1990a; Gaspar et al, 1990): induction (the period preceding visible cytological events); nucleus swelling; transverse and longitudinal first divisions of pericycle or cambial cells; continued cell divisions, without increase in gross volume, constituting morphogenetic radical fields (clusters of cells which show no polarity); volume increase of cell clusters by cell expansion and identification of radical meristems; internal growth of root primordia and root protrusion.

Table I shows results from leaved and nonleaved node cuttings of vine shoots raised in vitro, illustrating how these 2 cutting types differently entered into 5 well defined ontogenetic stages of root formation. Maximum rooting by leaved $(98 \%)$ and nonleaved $(95 \%)$ cuttings was reached after 156 and $168 \mathrm{~h}$ respectively. Leaved cuttings started the 5 successive ontogenetic stages somewhat earlier: swollen nuclei were seen in $40 \%$ of leaved cuttings at $33 \mathrm{~h}$; in $40 \%$ of nonleaved cuttings at $40 \mathrm{~h}$. Note that radical meristems did not occur before $110 \mathrm{~h}$. Evolution of specific peroxidase activity in the cuttings was characterized by an initial reduction during the first $12 \mathrm{~h}$, followed by an increase which culminated at $72 \mathrm{~h}$. Peroxidase activity decreased

Table I. Mean time (h) required by different percentages of the leaved (LC) and nonleaved (NLC) cuttings to reach the 5 ontogenetic status.

\begin{tabular}{lrrrrrrrr}
\hline \multirow{2}{*}{$\begin{array}{l}\text { Ontogenetic } \\
\text { status }\end{array}$} & \multicolumn{3}{c}{$L C$} & & & \multicolumn{3}{c}{$N C L$} \\
\cline { 2 - 3 } \cline { 6 - 7 } & $40 \%$ & $60 \%$ & $80 \%$ & & $40 \%$ & $60 \%$ & $80 \%$ \\
\hline A & 33 & 39 & 45 & & 40 & 52 & 59 \\
$\mathrm{~B}$ & 45 & 54 & 68 & & 57 & 64 & 76 \\
$\mathrm{C}$ & 78 & 81 & 92 & & 83 & 90 & 99 \\
$\mathrm{D}$ & 106 & 115 & 126 & & 111 & 119 & 130 \\
$\mathrm{E}$ & 128 & 136 & 142 & & 143 & 145 & 157 \\
\hline
\end{tabular}

A: nucleus swelling; $B$ : swollen nucleus and beginning of periclinal divisions in the cambium; $C$ : presence of morphogenetic fields; D: presence of radical meristems; $E$ : emergence of first root (from Moncousin et al, 1988). later, while the roots were appearing (fig $2 \mathrm{~A}$ ). No real difference could be observed between the leaved and the nonleaved cuttings. There was a clear increase in the content of free IAA in both types of cuttings, somewhat greater in the leaved ones, during the first $12 \mathrm{~h}$ (fig 2B). The IAA-level then began to decrease sharply to a minimum at $36 \mathrm{~h}$. This minimum was followed by a slow progressive increase.

The peroxidase peak preceding the emergence of root primordia found in other materials (see above) was again found here but this more critical analysis showed a prior passage through a minimum peroxidase activity (at $12 \mathrm{~h}$ ). This minimum corresponded to an early acute momentary peak of auxin level (fig 2B). The peak of peroxidase activity that culminated at $72 \mathrm{~h}$ (fig $2 \mathrm{~A})$ corresponded to a larger period of auxin depletion (fig 2B; see also Berthon et al, 1989). These results may explain the discrepancies in the results of investigations aimed at establishing a relationship between the amount of endogenous auxin-like substances in cuttings and their rooting performance (Nakano et al, 1980; Fouret
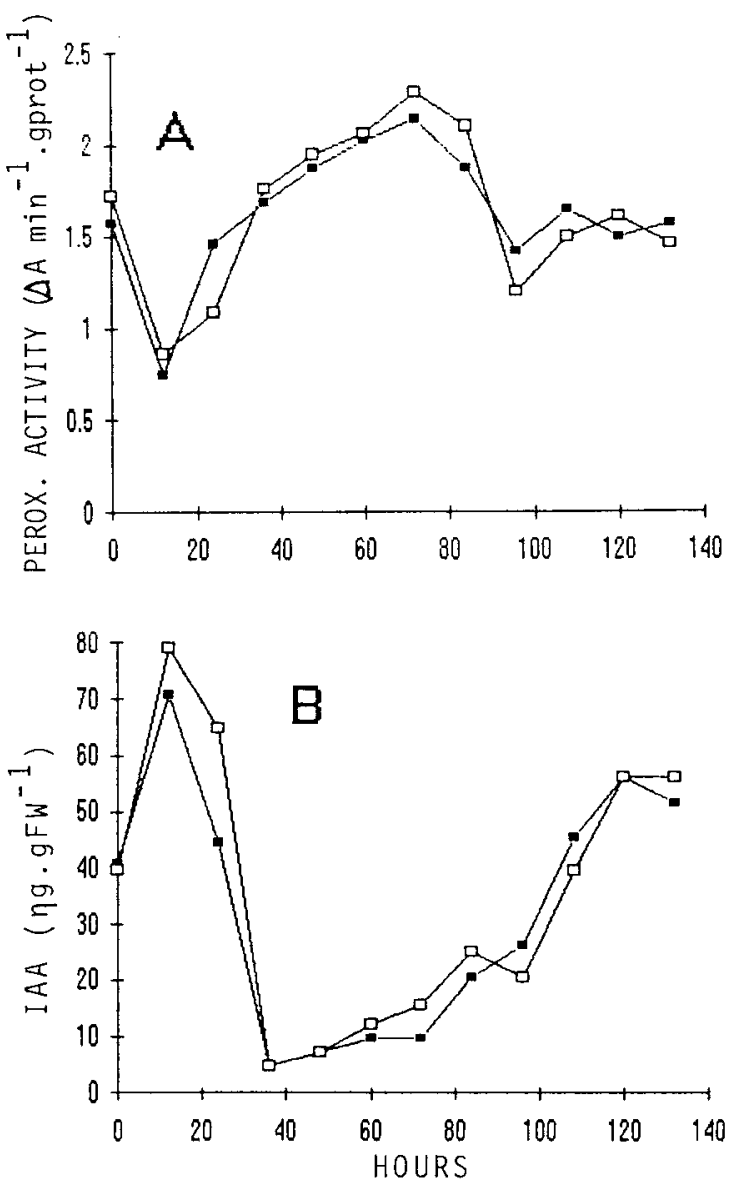

Fig 2. Evolution of specific peroxidase activity (A) and endogenous IAA level (B) in leaved $(0)$ and nonleaved $(\bullet)$ vine cuttings during the first $132 \mathrm{~h}$ on rooting medium (redrawn from Gaspar et al, 1990). 
et al, 1986; Welander and Snygg, 1987; Gaspar and Hofinger, 1988). The above analyses made in association with the ontogenetic phases of root formation indicate that the rooting inductive phase already terminated with the minimum of peroxidase activity at $12 \mathrm{~h}$, ie with the maximum auxin level; histological events began from that time and not as previously hypothesized from the peroxidase peak occurring later at $72 \mathrm{~h}$. The period of time between the peroxidase minimum (level of auxin maximum), and the peroxidase maximum might be qualified as the initiative phase of rooting, itself preceding an expressive one (Berthon et al, 1990a).

\section{PEROXIDASE ACTIVITY AS MARKER AND PREDICTOR OF THE ROOTING PERFORMANCE. PRACTICAL MANIPULATIONS TO IMPROVE ROOTING}

\section{Sorting out species or donor-plants with varying rooting abilities}

Before in vitro culture, buds from Prunus species known for their greater rooting ability were characterized by a higher peroxidase activity than species which rooted with difficulty (Quoirin et al, 1974). There was a similar relationship between the rhizogenetic potential of Asparagus donor plants and the peroxidase activity of their cuttings (Gaspar and Van Hoof, 1976). A positive correlation also occurred between the activity of (basic) peroxidases in stem of shoots of apple at the time of transfer to rooting medium and the number of roots formed later (Gus'kov et al, 1988; de Klerk et al, 1990).

\section{Physical and chemical treatments preparing rooting at the foregoing multiplication or elongation phase}

Although a direct relationship between the height of the peroxidase peak preceding rooting and the rooting rate was not always evident, treatments which enhanced peroxidase activity during the multiplication or elongation stage favoured rooting after transfer of the shoots to rooting medium. Benzyladenine used instead of kinetin in the multiplication medium of Asparagus provided a shoot population with a higher peroxidase activity and a higher rooting percentage (Gaspar and Van
Hoof, 1976). Continuous darkness instead of a 16-8 day-night cycle during elongation and root initiative phases of apple shoots favoured successive increase and decrease of peroxidase activity, and resulted in higher percentages of rooted plantlets (Druart et al, 1982). On the contrary, enhancement of peroxidase activity of globe artichoke shoots was favoured by continuous light, whereas a reduced photoperiod or darkness was necessary to achieve the decrease in peroxidase activity and to obtain rooting (Moncousin and Gaspar, 1983). The peroxidase peak appeared as a pivot time indicating when, most often, physical and/or chemical factors should be favourably changed. However, the requirements for increasing the peroxidase activity peak and principally for further lowering it as far and rapidly as possible (see hereafter), differ from plant to plant.

Substances which modify the rooting properties of exogenously applied auxins have been classified as auxin synergists or antagonists. Since the peroxidase (mediated IAA-oxidase) system has been shown to vary in an inverse manner throughout the phases of the rooting process (see above), such substances should have varying effects during the successive phases. We indeed have shown that compounds such as gibberellic acid and polyphenolic acids inhibit or stimulate root formation depending on the moment and duration of application (Gaspar et al, 1977). A simple classification between auxin synergists and antagonists thus no longer holds true (Gaspar, 1989).

\section{Precocity and performance of rooting in relation to peroxidase activity}

Results from investigations on Kalmia latifolia presented in table II and figure 3 allow the following conclusions to be made (Kevers et al, 1990, 1991; Kevers and Gaspar, 1992):

- peroxidase activity of the shoots transferred to rooting medium always increased to a peak;

- on bad rooting media (AND), the peroxidase peak was never completely reduced but was followed by several other peaks. Such a situation was also encountered with shoots from juvenile and mature clusters of Sequoiadendron giganteum (Berthon et al, 1987);

- on good rooting media (WPM 1/2) the peroxidase peak was unique and fell fairly rapidly; 
Table II. Characteristics of peroxidase activity peak in relation to the precocity and rooting percentage of Kalmia latifolia shoots (from Kevers and Gaspar, 1992).

\begin{tabular}{|c|c|c|c|c|c|c|}
\hline $\begin{array}{l}\text { Multiplication } \\
\text { media }\end{array}$ & $\begin{array}{l}\text { Rooting } \\
\text { media }\end{array}$ & $\begin{array}{l}\text { Timing } \\
\text { (d) }\end{array}$ & $\begin{array}{l}\text { Peroxidase peak } \\
\text { intensity } \\
\text { (1st peak) }\end{array}$ & $\begin{array}{l}\% \text { decrease } \\
\text { (in } 4 \text { d) }\end{array}$ & $\begin{array}{l}10 \% \\
\text { rooting at: } \\
\text { (d) }\end{array}$ & $\begin{array}{l}\% \\
\text { rooting } \\
(6 \mathrm{wk})\end{array}$ \\
\hline AND $x$ & $\begin{array}{l}\text { AND R } \\
\text { WPM 1/2 R } \\
\text { WPM 1/2 RC }\end{array}$ & $\begin{array}{l}10-20 \\
10 \\
6\end{array}$ & $\begin{array}{l}14.12 \\
6.83 \\
6.19\end{array}$ & $\begin{array}{l}- \\
25 \\
36\end{array}$ & $\begin{array}{l}- \\
22 \\
17\end{array}$ & $\begin{array}{l}7 \\
73 \\
67\end{array}$ \\
\hline WPM X & $\begin{array}{l}\text { AND R } \\
\text { WPM 1/2 R } \\
\text { WPM 1/2 RC }\end{array}$ & $\begin{array}{l}10-17 \\
6 \\
4\end{array}$ & $\begin{array}{l}11.25 \\
2.22 \\
2.22\end{array}$ & $\begin{array}{l}- \\
62 \\
67\end{array}$ & $\begin{array}{l}29 \\
15 \\
12\end{array}$ & $\begin{array}{l}13 \\
100 \\
100\end{array}$ \\
\hline AND $Y$ & $\begin{array}{l}\text { AND R } \\
\text { WPM } 1 / 2 R \\
\text { WPM } 1 / 2 \text { RC }\end{array}$ & $\begin{array}{l}6-13 \\
6 \\
4\end{array}$ & $\begin{array}{l}5.34 \\
1.45 \\
2.61\end{array}$ & $\begin{array}{l}- \\
31 \\
41\end{array}$ & $\begin{array}{l}- \\
16 \\
14\end{array}$ & $\begin{array}{l}7 \\
60 \\
60\end{array}$ \\
\hline WPM Y & $\begin{array}{l}\text { AND R } \\
\text { WPM 1/2 R } \\
\text { WPM 1/2 RC }\end{array}$ & $\begin{array}{l}2-13 \\
13 \\
6\end{array}$ & $\begin{array}{l}8.34 \\
4.71 \\
5.64\end{array}$ & $\begin{array}{l}- \\
72 \\
62\end{array}$ & $\begin{array}{l}38 \\
22 \\
15\end{array}$ & $\begin{array}{l}13 \\
100 \\
100\end{array}$ \\
\hline
\end{tabular}

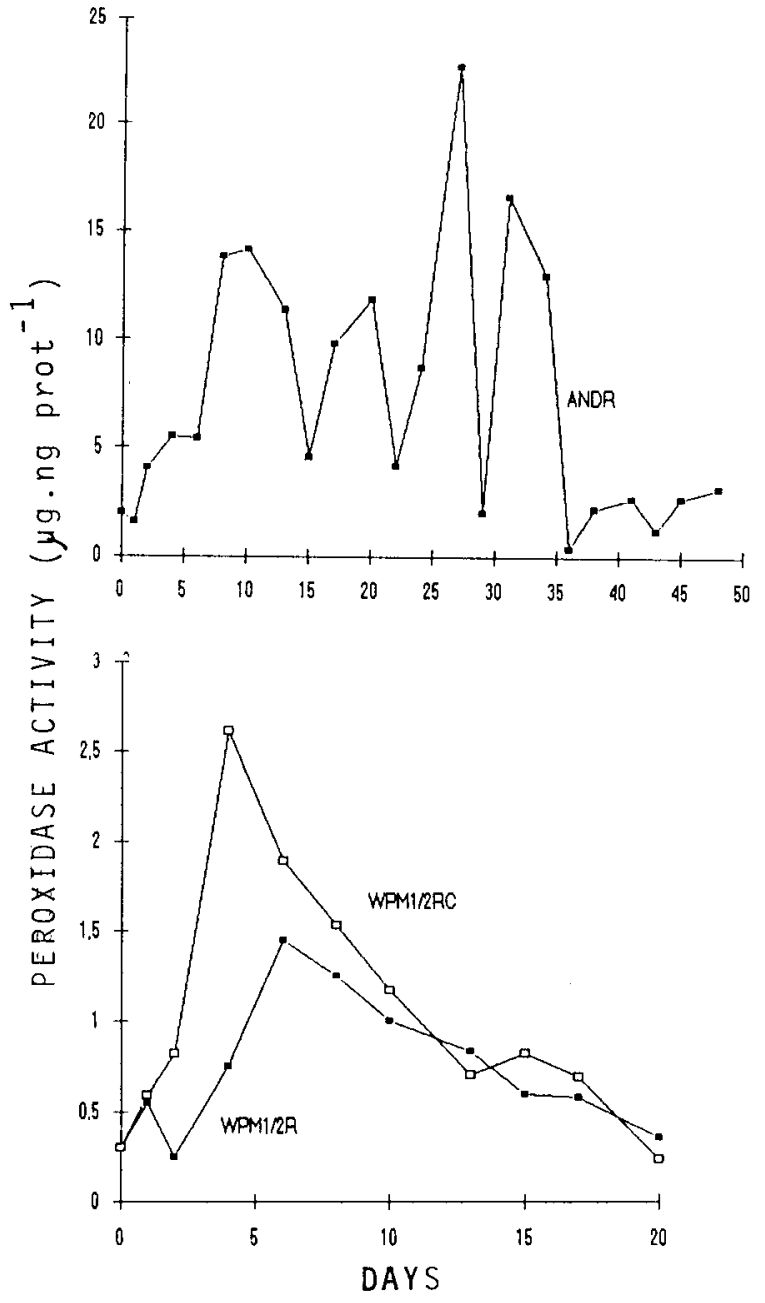

- there was no relationship of the percentage of rooting with the height of the peroxidase peak but with the velocity of the decrease of peroxidase activity. Shoots raised on thidiazuron instead of a cytokinin might fail to root adequately and showed an accompanying improper peroxidase decrease;

- there was also a relationship between the precocity of the peroxidase peak and the precocity of rooting.

These studies have again demonstrated that root formation does not depend only on the rooting media but also on the multiplication media used previously.

\section{An early test using phenolic compounds and peroxidase activity to improve rooting}

Investigations made on shoots of Sequoiadendron giganteum raised in vitro indicated that phenol compounds increased or decreased the in vitro rooting frequency depending on the time of

Fig 3. Changes in peroxidase activity of Kalmia latifolia shoots on poor (AND R) and good (WPM 1/2 R, WPM $1 / 2$ RC) rooting media. Rooting performance : WPM 1/2 RC > WPM 1/2 R > AND R (from Kevers and Gaspar, 1992). 
application, ie before the peroxidase peak (during so-called but inappropriately (see before) rootinginductive period) or starting with the peroxidase peak onwards (during the initiative-expressive phase of rooting) (Berthon et al, 1992). The same phenol compounds were also evaluated for their effects on peroxidase specific activity of extracts made from shoots before transferring to rooting media. Some of the compounds increased the specific activity, while other compounds decreased it. There was a strong correlation between the effect of phenolics on rooting and their effect on peroxidase activity (fig 4). For example, phenolic compounds that increased the peroxidase specific activity of shoot extracts also caused an increase in the rooting percentage when applied during the "induction" (phase corresponding to the elevation of peroxidase activity) phase of rhizogenesis, and vice versa. It has been proposed that this predictive assay might be used to increase the rooting percentage of other difficult to root species.

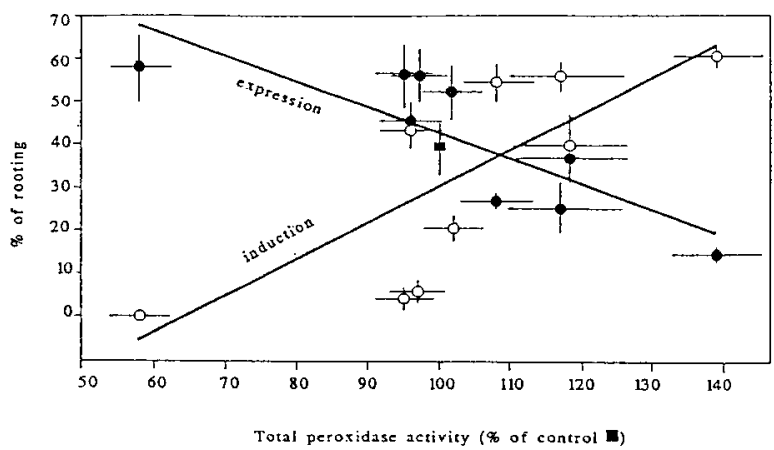

Fig 4. Correlation between the effect of phenol compounds on rooting and the effect of phenol compounds on peroxidase specific activity. Orthogonal regressions and correlations between the effect of phenol compounds on the rate of rooting, when applied at the induction $(O ; R=0.77 ; P=0.991)$ or expression phases $(O, R=0.81 ; P=0.996)$ of rhizogenesis, and the effect of the phenol compounds on peroxidase specific activity when added to an extract made from shoots before the induction of rhizogenesis. Bars represent the standard error (from Berthon et al, 1992). $\mathbf{m}$ : control in the absence of phenolic compound.

\section{ACKNOWLEDGMENTS}

This study was partly supported by the EEC ECLAIR project AGRE-CT91-0067. JYB and VR gratefully acknowledge the EEC grants which allow them to pursue research at the University of Liège. JFH is indebted to the Luxembourg Ministry of Cultural Affairs for a research fellowship.

\section{REFERENCES}

Aghmir A, Kevers C, Hausman JF, Gaspar T (1991) Peroxydases, compartimentation cellulaire et enracinement in vitro de pousses de Rhododendron catawbiense Michaux cv album. Arch Int Physiol Biochim $99,9 \mathrm{p}$

Ben Efraim J, Gad AE, Cohen P, Reymond P, Pilet $P E$ (1990) The effect of 4-chlororesorcinol on the endogenous levels of IAA, ABA and oxidative enzymes in cuttings. Plant Growth Regul 9, 97-106

Berthon JY, Boyer N, Gaspar T (1987) Sequential rooting media and rooting of Sequoiadendron giganteum in vitro. Peroxidase activity as a marker. Plant Cell Rep 6, 341-344

Berthon JY, Maldiney R, Sotta B, Gaspar T, Boyer N (1989) Endogenous levels of plant hormones during the course of adventitious rooting in cuttings of Sequoiadendron giganteum (Lindl) in vitro. Biochem Physiol Pflanz 184, 405-412

Berthon JY, Ben Tahar S, Gaspar T, Boyer N (1990a) Rooting phases of shoots of Sequoiadendron giganteum in vitro and their requirements. Plant Physiol Biochem 28, 631-638

Berthon JY, Boyer N, Gaspar T (1990b) Phenols as regulators and markers of root formation by shoots of Sequoiadendron giganteum raised in vitro. Arch Int Physiol Biochem 98, 28 p

Berthon JY, Battraw MJ, Gaspar T, Hofinger M, Boyer $N$ (1992) Early test using phenolic compounds and peroxidase activity to improve in vitro rooting of Sequoiadendron giganteum (Lindl). Buchholz (submitted)

Bhattacharya NC (1988) Enzymes activities during adventitious rooting. In: Adventitious Root Formation in Cuttings (Davis TD, Haissig BE, Sankhla N, eds) Dioscorides Press, Portland, OR, vol 2, 88-101

Chandra GR, Gregory LE, Worley JF (1971) Studies on the initiation of adventitious root on mung bean hypocotyl. Plant Cell Physiol 12, 317-324

Curir $P$, Van Sumere $C$, Termini A, Barthe $P$, Marchesini A, Dolci M (1989) Flavonoids accumulation is correlated with adventitious root formation in Eucalyptus gunnii Hook micropropagated through axillary bud stimulation. Plant Physiol 92, 1148-1153

Dalet F, Cornu D (1986) Les peroxydases : marqueurs enzymatiques de l'enracinement in vitro du merisier (Prunus avium L). Bull Groupe Polyphénols 13, 213-215

Dalet F, Cornu D (1989) Lignification level and peroxidase activity during in vitro rooting of Prunus avium. Can J Bot 67, 2182-2186

Davis TD, Haissig BE, Sankhla N (1988) Adventitious Root Formation in Cuttings. Dioscorides Press, Portland, OR

de Klerk G, ter Brugge J, Smulders R, Benschop M (1990) Basic peroxidases and rooting in microcuttings of Malus. Acta Hortic 280, 29-36 
Druart P, Kevers C, Boxus P, Gaspar T (1982) In vitro promotion of root formation by apple shoots through darkness effect on endogenous phenols and peroxidases. Z Pflanzenphysiol 108, 429-436

Favre JM (1973) Effets corrélatifs de facteurs internes et externes sur la rhizogenèse de la vigne (Vitis riparia $\times$ Vitis rupestris), cultivée in vitro. Rev Gén Bot 80, 279-361

Fouret $Y$, Arnaud $Y$, Maldiney $R$, Sotta $B$, Miginiac $E$ (1986) Relation entre rhizogenèse et teneur en auxine et acide abscissique chez trois clones de Sequoidendron sempervirens (Endl) issus d'arbres d'âge différent. CR Acad Sci Paris 303 (ser III), 135-138

Gaspar T (1981) Rooting and flowering, two antagonistic phenomena from a hormonal point of view. In: Aspects and Prospects of Plant Growth Regulation (Jeffcoat B, ed) Br Plant Growth Regul Group, Wantage, UK, Monogr No 6, 39-49

Gaspar T (1989) Root formation, vitrification, calli: changing concepts. News Bull Br Plant Growth Regul Group 11, 1-7

Gaspar T, Van Hoof (1976) Application d'un test peroxydasique dans le choix des plantes d'asperges à propager in vitro. Rev Agric 3, 583-592

Gaspar T, Smith D, Thorpe T (1977) Arguments supplémentaires en faveur d'une variation inverse du niveau auxinique endogène au cours des deux premières phases de la rhizogenèse. $C R$ Acad $\mathrm{SCi}$ Paris 285, 327-330

Gaspar T, Penel C, Thorpe T, Greppin H (1982) Peroxidases 1970-1980. A Survey of Their Biochemi$\mathrm{cal}$ and Physiological Roles in Higher Plants. Univ Geneva, Botanical Center

Gaspar T, Coumans M (1987) Root formation. In: Cell and tissue culture in forestry (Bonga JM, Durtzan DJ, eds). Martinus Nijhoff, Dordrecht, Vol 2, 202217

Gaspar T, Hofinzer M (1988) Auxin metabolism during adventitious rootin. In: Adventitious Root Formation in Cuttings (Davis TD, Haissig BL, Sankla N, eds) Dioscorides Press, Portland, 117-131

Gaspar T, Moncousin C, Greppin H (1990) The place and role of exogenous and endogenous auxin in adventitious root formation. In: Intra- and InterCellular Communications in Plants - Reception Transmission - Storage and Expression of Messages (Millet B, Greppin H, eds) INRA, Paris, 125139

Gebhardt K (1985) Self-rooted sour cherries in vitro: auxin effect on rooting and isoperoxidases. Acta Hortic 169, 341-349

Gebhardt K (1986) The possible effect of peroxidases/ IAA oxidase stimulation on rooting of sour cherries in vitro. In: Molecular and Physiological Aspects of Plant Peroxidases (Greppin H, Penel C, Gaspar T, eds) Univ Geneva, 387-393

Gonzalez A, Tames RS, Rodriguez R (1991) Ethylene in relation to protein, peroxidase and polyphenol oxidase activities during rooting in hazelnut cotyledons. Physiol Plant 83, 611-620

Gurumurti K, Gupta BB, Kumar A (1984) Hormonal regulation of root formation. In: Hormonal Regulation of Plant Growth and Development (Purohit SS, ed) Agro Bot Publ, Bikaner, India, 387-400

Gus'kov AV, Tikhomirov IA, Polikarpova FY (1988) Peroxidase activity in apple clone stocks with different capacity for rhizogenesis. Fiziol Rast 35, 945954

Haissig BE (1986) Metabolic process in adventitious rooting of cuttings. In: New Root Formation in Plants and Cuttings (Jackson MB, ed) Martinus Nijhoff Publ, Dordrecht, 141-189

Hausman JF, Kevers C, Gaspar T (1990) Rooting in vitro while multiplying. Arch Int Physiol Biochim 98, $42 p$

Jackson MB (1986) New Root Formation in Plant and Cuttings. Martinus Nijhoff Publ, Dordrecht

Jarvis BC (1986) Endogenous control of adventitious rooting in non-woody cuttings. In: New Root Formation in Plants and Cuttings (Jackson MB, ed) Martinus Nijhoff Publ, Dordrecht, 191-222

Kevers C, Gaspar T (1992) Micropropagation of Kalmia latifolia: acclimation and rooting performance dependent on the preceding steps. Relationship with peroxidase activity. Med Fac Landbouw Rijksuniv Gent 57/3b, 977-985

Kevers C, Menard D, Marchand S, Hausman JF, Gaspar T (1990) Enracinement in vitro et ex vitro et comportement à l'acclimatation de Kalmia et de Rhododendrons multipliés in vitro. Med Fac Landbouww Rijksuniv Gent 55, 1267-1273

Kevers C, Hausman JF, Hagege D, Gaspar T (1991) Post-effect of thidiazuron on peroxidase activity and rooting of microcuttings of Kalmia latifolia. Saussurea $22,27-31$

Mato MC, Vieitez AN (1986) Changes in auxin protectors and IAA oxidases during the rooting of chestnut shoots in vitro. Physiol Plant 66, 491-494

Mato MC, Rua ML, Ferro E (1988) Biochemical changes during root formation in Vitis cultured in vitro. Physiol Plant 72, 84-88

Millet B, Greppin H (1990) Intra- and Inter-Cellular Communications in Plants-Reception-TransmissionStorage and Expression of Messages. INRA, Paris

Mitsuhashi-Kato $M$, Shibaoka $H$, Shimokoriyama RJ (1978a) Anatomical and physiological aspects of development processes of adventitious root formation in Azukia cuttings. Plant Cell Physiol 19, 393400

Mitsuhashi-Kato M, Shibaoka $H$, Shimokoriyama RJ (1978b) The nature of the dual effect of auxin on root formation in Azukia cuttings. Plant Cell Physiol $19,1535-1542$

Molnar JM, Lacroix LJ (1972) Studies on the rooting of cuttings of Hydrangea macrophylla: enzyme changes. Can J Bot 50, 315-322 
Moncousin C (1991) Rooting of in vitro cuttings. In: Biotechnology and Forestry (17) - High-Tech and Micropropagation I (Bajaj YPS, ed) Springer Verlag, Berlin, 231-261

Moncousin C, Gaspar T (1983) Peroxidase as a marker for rooting improvement of Cynara scolymus $L$ cultured in vitro. Biochem Physiol Pflanz 178, 263-271

Moncousin C, Favre JM, Gaspar T (1988) Changes in peroxidase activity and endogenous IAA levels during adventitious rooting in vine cuttings. In: Physiology and Biochemistry of Auxins in Plants (Kutacek $\mathrm{M}$, Bandurski RS, Krekule J, eds) Academia, Prague, 331-337

Nakano M, Yuda E, Nakiagawa S (1980) Studies on rooting of hardwood cuttings of grapevine, cv Delaware. Jpn Soc Hortic Sci 48, 385-394

Patience PA, Alderson PG (1987) Development of a system to study peroxidases during the rooting of lilac shoots produced in vitro. Acta Hortic 212, 267272
Pilet PE, Gaspar T (1968) Le Catabolisme Auxinique. Monographie de Physiologie Végétale No 1. Masson, Paris, $148 p$

Pythoud F, Buchala AJ (1989) Peroxidase activity and adventitious rooting in cuttings of Populus tremula L. Plant Physiol Biochim 27, 503-510

Quoirin M, Boxus P, Gaspar T (1974) Root initiation and isoperoxidases of stem tip cuttings from mature Prunus plants. Physiol Vég 12, 165-174

Thorpe TA, Tran Than Van M, Gaspar T (1978) Isoperoxidase in epidermal layers of tobacco and changes during organ formation in vitro. Physiol Plant 44, 388-394

Van Hoof P, Gaspar T (1976) Peroxidase and isoperoxidase changes in relation to root initiation of Asparagus cultured in vitro. Sci Hortic 4, 27-31

Welander M, Snygg JO (1987) Effect of applied and endogenous auxin on callus and root formation of in vitro shoots of the apple rootstocks M-26 and A2. Ann Bot 59, 439-443 